\title{
Optimising Wound Closure Following a Fasciotomy A narrative review
}

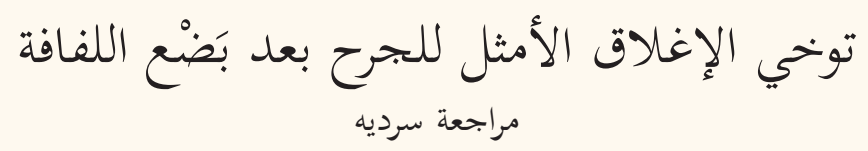

$$
\text { محمد خليفة الخليفة و فريد سعيد هليل المطيري }
$$

\begin{abstract}
Compartment syndrome is a surgical emergency that could be resolved by a fasciotomy. However, performing substantial skin incisions may lead to life-threatening complications. This narrative review aimed to present the available methods of wound closure and preferential factors for using each technique. Viable and noninfected wounds were most often treated by gradual approximation techniques, such as the simple or modified shoelace technique, the prepositioned intracutaneous suture or several commercially-available mechanical devices. In addition, applying negative pressure therapy was found to be feasible, particularly when combined with approximation techniques. Skin grafting was reserved for severely-dehiscent wounds while other non-invasive approaches were considered for other subsets of patients with inadvisable surgical interventions. Treatment decision should be made in view of the patient's condition, ease of application, availability of resources, cost of treatment and aesthetic outcomes.
\end{abstract}

Keywords: Compartment Syndrome; Fasciotomy; Wound Closure Techniques; Negative-Pressure Wound Therapy.

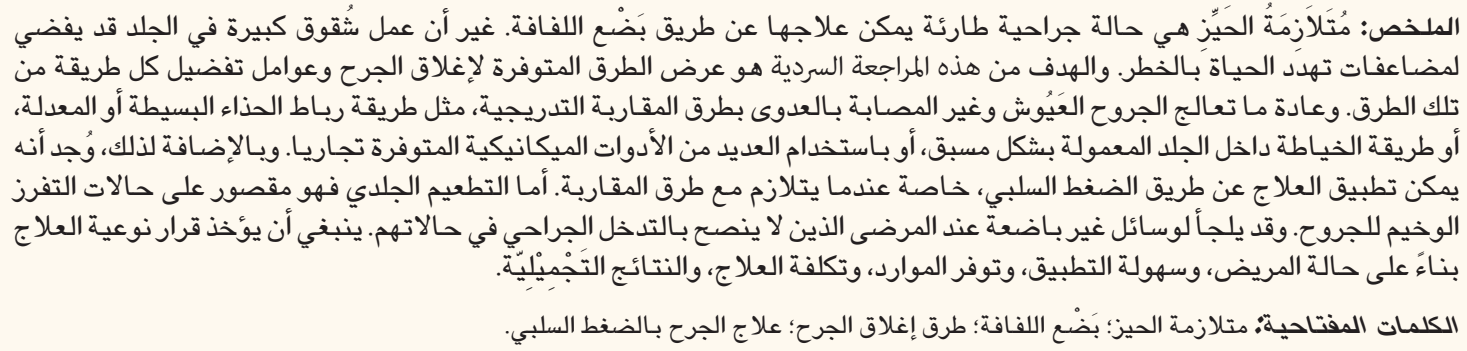

$\mathrm{C}$

OMPARTMENT SYNDROME (CS) IS A SURGICAL emergency condition that requires a timely diagnosis to preclude a potentially devastating outcome. It involves an increase in the intracompartmental pressure (ICP) due to an imbalance in homeostasis among the arterial flow, venous pressure and ICP. ${ }^{1}$ CS is caused by vascular obstruction, fracture, injuries (e.g. crush or electrical injuries), excessive use of muscles and/or iatrogenic factors. The affected compartments may involve any muscle surrounded by fascia and are not limited to the axial skeleton; however, it mostly affects the compartments of the legs and, to a lesser extent, the compartments of the shoulders, arms, forearms, hands, thighs and buttocks. ${ }^{2}$ Soft tissue necrosis and permanent disability may occur due to improper management. The gold standard for CS treatment includes a fasciotomy by performing an incision through the skin, fat and muscular fascia in order to reveal the underlying compartment and reduce the established pressure.

However, approximately $4-38 \%$ of the managed patients will develop unfavourable complications. In addition, failure of early identification of these complications has been associated with a two-fold increase in amputation rates and a four-fold increase in the risk of mortality. ${ }^{3,4}$ Furthermore, 77\% and 26\% of patients can experience paraesthesia and tethered scars, respectively, which would lead to a significant reduction in quality of life., ${ }^{5,6}$ Therefore, despite the importance of reducing pressure in the muscular compartments, surgical treatment of CS should only be performed after careful consideration of the postoperative aspects, such as pressure threshold and the degree of suspicion. However, early management of 
fasciotomy wounds is generally not recommended due to potential tissue oedema that may lead to necrosis, infection or recurrence of CS. This may eventually compromise the associated vascular pathology and/ or fracture. Hence, fasciotomy performed for both therapeutic and prophylactic purposes should be managed as an open wound during the first 2-3 days followed by a primary closure of the wound.?

All wound closure techniques exploit the inherent viscoelastic and biomechanical properties of the skin. ${ }^{8}$ A successful wound closure is defined as closure without the need for skin grafting, amputation or death, ${ }^{4}$ for which there are numerous methods with various outcomes and can represent a challenge in terms of both timing and safety. This narrative review aimed to provide insights into the current techniques and their preferential application in selected groups of patients. The indications, complications, advantages and disadvantages of each procedure have been emphasised to ascertain the best approach to optimise wound closure.

\section{Skin Grafting}

In patient who underwent fasciotomies, skin grafting has been used for some time due to its safety, low cost and convenient dressing procedures compared to other delayed primary closure techniques. ${ }^{9}$ Splitthickness skin grafting (STSG) is the treatment of choice for early coverage of fasciotomy wounds with persistent oedema and skin retraction. In a recent retrospective cohort study in the USA, STSG was the main surgical indication (40\% of patients) for wounds for which primary closure was not possible due to swelling, whereas delayed primary closure techniques were utilised in only $18 \%$ of patients. ${ }^{9}$ STSG was performed if the patient had either remarkable swelling of the lower extremity or open fractures and was more frequently performed on patients with proximal or tibial plateau fractures than patients with midshaft or distal fractures. This technique resulted in a significant reduction in the length of hospital stay (LOS) compared to other techniques. ${ }^{10}$ In contrast, a larger retrospective study in the USA found that STSG procedures were associated with longer LOS compared to either vacuum dressing or dynamic tension-based techniques. ${ }^{11}$

In general, when applying tension via delayed primary closure is not possible, STSG may be the only available option for managing persistently dehiscent wounds, burns and wounds with a poor and friable edge. ${ }^{7,12}$ Although the cost of STSG procedures increases due to long operative times and supplies required for grafting, this technique may be cost-effective due to shorter LOS and less frequent additional procedures compared to primary closure techniques. However, the STSG technique does have some limitations. Patients might experience pain at the donor site wound with noticeable scarring; this may increase the patient's morbidity and reduce mobilisation. Scarring can also occupy a wide area over the fasciotomy site and could affect the muscular function in the compartment. Furthermore, STSG procedures may be associated with cosmetic issues, adhesions between the muscles and tendons and reduced skin sensitivity [Table 1]. ${ }^{13}$

\section{Negative-Pressure Therapy}

Since its introduction and development in the late 1990s, vacuum-assisted closure (VAC) has been used in order to close a wide variety of wound types and has contributed significantly to the improvement of healing and reduced requirements for reconstructive procedures. ${ }^{14}$ VAC induces tissue microstrain that enhances wound healing by improving angiogenesis and cell division, discards the bacteria-rich exudate from wound edges and removes oedema from the extracellular matrix thereby improving the local blood flow and reducing proinflammatory cytokines. ${ }^{14,15}$ As a result, healing of the marginalised tissue would be improved and progressive tissue necrosis may be reduced, which is of particular importance in reversing the CS-induced pathological changes. Furthermore, VAC dressings may have an advantageous role in bridging soft tissues following severe trauma associated with marked tissue loss. ${ }^{16}$ With this technique, flap coverage may be omitted entirely in selected patients. ${ }^{17}$

For the management of fasciotomy wounds, VAC provides a powerful adjunct to surgical management or it can be utilised on its own. It decreases wound closure time, facilitates wound healing, reduces the time needed for a skin graft and increases the number of patients who can be good candidates for a feasible primary closure. ${ }^{16}$ In open fasciotomy wounds, VAC dressings should be changed every 2-3 days either at bedside or in the operating room for large-sized wounds for better wound visualisation, irrigation and to ultimately maximise the chances of achieving staged primary closure or decreasing the size of skin grafts.

Yang et al. reviewed the records of 34 VACmanaged patients following leg fasciotomy procedures and found that the average time required for wound closure decreased significantly compared to matched controls (6.7 versus 16.1 days). ${ }^{18}$ Weiland used hyperbaric oxygen in conjunction with VAC in order to enhance the reduction of oedema and found that wound closure ranged from 3-18 days in three patients. ${ }^{19}$ 
Table 1: Summary of studies investigating skin-grafting and dermal approximation techniques for primary wound closure after fasciotomy

\begin{tabular}{|c|c|c|c|c|c|c|c|}
\hline $\begin{array}{l}\text { Author and } \\
\text { year of study }\end{array}$ & $\begin{array}{l}\text { Location of } \\
\text { study }\end{array}$ & Study design & $\begin{array}{l}\text { Indication for } \\
\text { fasciotomy }\end{array}$ & $\begin{array}{c}\text { Type of } \\
\text { treatment and } \\
\text { sample size }\end{array}$ & Material used & $\begin{array}{l}\text { Mean time } \\
\text { to primary } \\
\text { wound closure } \\
\text { in days } \pm S D\end{array}$ & Type of complication \\
\hline \multicolumn{8}{|l|}{ VAC technique } \\
\hline \multirow{2}{*}{$\begin{array}{l}\text { Bussell et al. }{ }^{27} \\
(2018)\end{array}$} & \multirow[t]{2}{*}{ Switzerland } & \multirow[t]{2}{*}{ Retrospective } & \multirow{2}{*}{$\begin{array}{l}\text { Ischaemia, } \\
\text { fractures } \\
\text { and systemic } \\
\text { diseases }\end{array}$} & - $\operatorname{VAC}(\mathrm{n}=19)$ & - & $9.37 \pm 4.67$ & - STSG $(\mathrm{n}=1)$ and WI $(\mathrm{n}=1)$ \\
\hline & & & & $\begin{array}{l}\text { - Temporary } \\
\text { synthetic skin } \\
\text { replacement } \\
(\mathrm{n}=9)\end{array}$ & $\begin{array}{l}\text { - Epigard }{ }^{\circledR} \\
\text { (Biovision GmbH, } \\
\text { Ilmenau, Germany) }\end{array}$ & $4.89 \pm 2.32$ & $\bullet$ None \\
\hline \multirow[t]{2}{*}{$\begin{array}{l}\text { Krticka et al. }{ }^{23} \\
(2018)\end{array}$} & \multirow[t]{2}{*}{$\begin{array}{l}\text { Czech } \\
\text { Republic }\end{array}$} & \multirow[t]{2}{*}{ Retrospective } & \multirow[t]{2}{*}{ Fracture } & - $\operatorname{VAC}(\mathrm{n}=42)$ & - $\mathrm{SF}=125 \mathrm{mmHg}$ & 11 & $\begin{array}{l}\text { - STSG }(n=7), \text { WI }(n=4) \text {, } \\
\text { osteomyelitis }(n=2) \text { and } \\
\text { muscle necrosis }(n=3)\end{array}$ \\
\hline & & & & $\begin{array}{l}- \text { Control } \\
(\mathrm{n}=21)\end{array}$ & $\begin{array}{l}\text { - Combined } \\
\text { dressing fabric }\end{array}$ & 17 & $\begin{array}{l}\text { - STSG }(\mathrm{n}=10) \text {, WI }(\mathrm{n}=7) \text {, } \\
\text { osteomyelitis }(\mathrm{n}=3) \text { and } \\
\text { muscle necrosis }(\mathrm{n}=9)\end{array}$ \\
\hline Lee $^{20}(2016)$ & USA & Case series & $\begin{array}{l}\text { Complicated } \\
\text { wounds }\end{array}$ & - $\operatorname{VAC}(\mathrm{n}=2)$ & $\begin{array}{l}- \text { VAC with } \\
\text { instillation and } \\
\text { dwell dime } \\
(\mathrm{SF}=125 \mathrm{mmHg})\end{array}$ & - & - None \\
\hline \multirow{2}{*}{$\begin{array}{l}\text { Saziye et al. }{ }^{17} \\
\text { (2011) }\end{array}$} & \multirow[t]{2}{*}{ Switzerland } & \multirow[t]{2}{*}{ Retrospective } & \multirow[t]{2}{*}{ IRI } & - $\operatorname{VAC}(\mathrm{n}=7)$ & - $\mathrm{SF}=75-125 \mathrm{mmHg}$ & $11 \pm 8-13$ & - STSG $(\mathrm{n}=2)$ \\
\hline & & & & $\begin{array}{l}\text { - Conservative } \\
\text { dressing }(\mathrm{n}=8)\end{array}$ & - Gauze dressings & $15 \pm 12-20$ & - WI (n = 3) \\
\hline \multirow{2}{*}{$\begin{array}{l}\text { Weaver et al. }{ }^{10} \\
(2015)\end{array}$} & \multirow[t]{2}{*}{ USA } & \multirow[t]{2}{*}{ Retrospective } & \multirow{2}{*}{$\begin{array}{l}\text { Fractures and } \\
\text { soft tissue } \\
\text { injuries }\end{array}$} & - $\operatorname{VAC}(\mathrm{n}=22)$ & - & 14.7 & - No information available \\
\hline & & & & - $\operatorname{STSG}(\mathrm{n}=82)$ & - & 12.2 & - No information available \\
\hline \multirow{2}{*}{$\begin{array}{l}\text { Zannis et al. }{ }^{16} \\
(2009)\end{array}$} & \multirow[t]{2}{*}{ USA } & \multirow[t]{2}{*}{ Retrospective } & \multirow{2}{*}{$\begin{array}{l}\text { Fractures and } \\
\text { soft tissue } \\
\text { injuries }\end{array}$} & - $\operatorname{VAC}(\mathrm{n}=68)$ & - $\mathrm{SF}=125 \mathrm{mmHg}$ & 7.1 & - STSG $(\mathrm{n}=29)$ \\
\hline & & & & $\begin{array}{l}\text { - Wet-to-dry } \\
\text { dressings } \\
(\mathrm{n}=74)\end{array}$ & $\begin{array}{l}\text { - Normal saline- } \\
\text { soaked dressings }\end{array}$ & 9.6 & - STSG $(\mathrm{n}=35)$ \\
\hline \multicolumn{8}{|c|}{ Shoelace technique } \\
\hline $\begin{array}{l}\text { Branco et al. } .^{31} \\
(2016)\end{array}$ & Brazil & Case report & Open fracture & $\mathrm{n}=1$ & $\begin{array}{l}\text { - Elastic suture } \\
\text { system }\end{array}$ & 7 & - None \\
\hline $\begin{array}{l}\text { Erdös et al. } .^{37} \\
(2011)\end{array}$ & Austria & Case series & $\begin{array}{l}\text { CS due to } \\
\text { fractures and } \\
\text { contusion of soft } \\
\text { tissues }\end{array}$ & $\mathrm{n}=24$ & $\begin{array}{l}\text { - Elastic vessel } \\
\text { loop with stables } \\
\text { and VAC }\end{array}$ & 11.9 & - $\operatorname{STSG}(\mathrm{n}=3)$ \\
\hline $\begin{array}{l}\text { Lee } \text { et } a l .^{21} \\
(2014)\end{array}$ & South Korea & Case series & $\begin{array}{l}\text { Necrotising } \\
\text { fasciitis }\end{array}$ & $\mathrm{n}=8$ & $\begin{array}{l}- \text { Elastic vessel } \\
\text { loop with stables } \\
\text { and VAC }\end{array}$ & 16 & - $\operatorname{STSG}(\mathrm{n}=2)$ \\
\hline $\begin{array}{l}\text { Matt et al. }{ }^{11} \\
(2011)\end{array}$ & USA & Retrospective & $\begin{array}{l}\text { Fractures and } \\
\text { soft tissue } \\
\text { injuries }\end{array}$ & $\mathrm{n}=24$ & $\begin{array}{l}\text { - Elastic vessel } \\
\text { loop with stables } \\
\text { and VAC }\end{array}$ & 16 & $\begin{array}{l}\text { - STSG }(\mathrm{n}=4) \text { and } \\
\text { WI }(\mathrm{n}=2)\end{array}$ \\
\hline $\begin{array}{l}\text { Murakami et } \\
\text { al.36 } \\
(2014)\end{array}$ & Japan & Case report & Soft tissue injury & $\mathrm{n}=1$ & $\begin{array}{l}\text { - Elastic vessel } \\
\text { loop with stables } \\
\text { and VAC }\end{array}$ & 7 & - None \\
\hline $\begin{array}{l}\text { Saini et al. }{ }^{30} \\
\text { (2018) }\end{array}$ & India & Prospective & $\begin{array}{l}\text { Fractures and } \\
\text { soft tissue } \\
\text { injuries }\end{array}$ & $\mathrm{n}=19$ & - Silk sutures & 8.31 & - WI (n = 1) \\
\hline $\begin{array}{l}\text { Sawant and } \\
\text { Hallet }^{34}(2001)\end{array}$ & UK & $\begin{array}{l}\text { Technique } \\
\text { description }\end{array}$ & - & - & $\begin{array}{l}\text { - Elastic vessel } \\
\text { loop with stables }\end{array}$ & - & - No information available \\
\hline $\begin{array}{l}\text { Zorrilla et al. }{ }^{54} \\
\text { (2005) }\end{array}$ & Spain & Retrospective & $\begin{array}{l}\text { Fractures and } \\
\text { soft tissue } \\
\text { injuries }\end{array}$ & $\mathrm{n}=20$ & $\begin{array}{l}\text { - Elastic vessel } \\
\text { loop with stables }\end{array}$ & 8.8 & - None \\
\hline \multicolumn{8}{|c|}{ Shoelace versus VAC technique } \\
\hline \multirow[t]{2}{*}{$\begin{array}{l}\text { Fowler et al. }{ }^{25} \\
(2012)\end{array}$} & \multirow[t]{2}{*}{ USA } & \multirow[t]{2}{*}{ Case series } & \multirow{2}{*}{$\begin{array}{l}\text { Fractures and } \\
\text { soft tissue } \\
\text { injuries }\end{array}$} & $\begin{array}{l}\text { - Shoelace } \\
(\mathrm{n}=49)\end{array}$ & $\begin{array}{l}\text { - Elastic vessel } \\
\text { loop with stables }\end{array}$ & 19.2 & $\begin{array}{l}\text { - STSG }(\mathrm{n}=9) \text { and WI } \\
(\mathrm{n}=3)\end{array}$ \\
\hline & & & & - $\operatorname{VAC}(\mathrm{n}=7)$ & $\begin{array}{l}\text { - VAC device } \\
\text { (Kinetic Concepts, } \\
\text { Inc., San Antonio, } \\
\text { Texas, USA) }\end{array}$ & 23.7 & $\begin{array}{l}\text { - STSG }(\mathrm{n}=4) \text { and WI } \\
(\mathrm{n}=2)\end{array}$ \\
\hline \multirow[t]{2}{*}{$\begin{array}{l}\text { Johnson et al. }{ }^{28} \\
\text { (2018) }\end{array}$} & \multirow[t]{2}{*}{ USA } & \multirow[t]{2}{*}{ RCT } & \multirow[t]{2}{*}{$\begin{array}{l}\text { Traumatic } \\
\text { injuries }\end{array}$} & $\begin{array}{l}\text { - Shoelace } \\
(\mathrm{n}=5)\end{array}$ & $\begin{array}{l}\text { - Elastic vessel } \\
\text { loop with stables }\end{array}$ & 7.6 & - No information available \\
\hline & & & & - $\operatorname{VAC}(\mathrm{n}=9)$ & - & 12.9 & - No information available \\
\hline
\end{tabular}

$S D=$ standard deviation; VAC = vacuum-assisted closure; $S T S G=$ spilt-thickness skin grafting; $W I=$ wound infection; $S F=$ suction force; $I R I=$ ischaemia-reperfusion injury; $C S=$ compartment syndrome; $R C T=$ randomised controlled trial. 
Table 1 (contd.): Summary of studies investigating skin-grafting and dermal approximation techniques for primary wound closure after fasciotomy

\begin{tabular}{|c|c|c|c|c|c|c|c|}
\hline \multirow[t]{2}{*}{$\begin{array}{l}\text { Kakagia et al. } .^{24} \\
(2014)\end{array}$} & \multirow[t]{2}{*}{ Greece } & \multirow[t]{2}{*}{$\mathrm{RCT}$} & \multirow{2}{*}{$\begin{array}{l}\text { Fractures and } \\
\text { soft tissue } \\
\text { injuries in the } \\
\text { leg }\end{array}$} & - Shoelace $(\mathrm{n}=25)$ & $\begin{array}{l}\text { - Silastic vessel } \\
\text { loop with stables }\end{array}$ & $15.1 \pm 3.8$ & - WI $(\mathrm{n}=4)$ \\
\hline & & & & - $\operatorname{VAC}(\mathrm{n}=25)$ & - $\mathrm{SF}=125 \mathrm{mmHg}$ & $19.1 \pm 6.1$ & - STSG $(n=6)$ and WI $(n=6)$ \\
\hline \multicolumn{8}{|l|}{ Suture technique } \\
\hline $\begin{array}{l}\text { Chiverton } \\
\text { and Redden }{ }^{40} \\
(2000)\end{array}$ & UK & Case series & $\begin{array}{l}\text { Fracture of the } \\
\text { lower limb }\end{array}$ & $\mathrm{n}=6$ & $\begin{array}{l}\text { - Prepositioned } \\
\text { intracutaneous } \\
\text { suture }\end{array}$ & - & - Broken suture $(\mathrm{n}=1)$ \\
\hline $\begin{array}{l}\text { Dahners }{ }^{55} \\
(2003)\end{array}$ & USA & $\begin{array}{l}\text { Technique } \\
\text { description }\end{array}$ & & & $\begin{array}{l}\text { - Running near- } \\
\text { near-far-far } \\
\text { suture }\end{array}$ & - & - None \\
\hline $\begin{array}{l}\text { Janzing and } \\
\operatorname{Broos}^{39}(2001)\end{array}$ & Belgium & Case series & - & $\mathrm{n}=5$ & $\begin{array}{l}\text { - Prepositioned } \\
\text { intracutaneous } \\
\text { suture }\end{array}$ & $9 \pm 3.5$ & $\begin{array}{l}\text { - Second operation }(\mathrm{n}=2) \text {. } \\
\text { Traction under anaesthesia } \\
\text { because of pain in one } \\
\text { patient and another patient } \\
\text { required additional sutures }\end{array}$ \\
\hline $\begin{array}{l}\text { Van der Velde } \\
\text { and Hudson } \\
(2005)\end{array}$ & South Africa & Prospective & - & $\mathrm{n}=11$ & $\begin{array}{l}\text { - Bootlace nylon } \\
\text { suture and VAC }\end{array}$ & 7.5 & $\begin{array}{l}\text { - Skin necrosis }(n=1) \text {, } \\
\text { broken suture }(n=1) \text { and } \\
\text { vacuum leak }(n=1)\end{array}$ \\
\hline \multicolumn{8}{|c|}{ Static tension strips technique } \\
\hline $\begin{array}{l}\text { Harrah et al. }{ }^{42} \\
(2000)\end{array}$ & USA & $\begin{array}{l}\text { Technique } \\
\text { description }\end{array}$ & IRI & $\mathrm{n}=6$ & - Plaster strips & - & - None \\
\hline Weissman et al..$^{33}$ & Israel & Case series & - & $\mathrm{n}=4$ & - Plaster strips & 21 & - Hypertrophic scar $(\mathrm{n}=1)$ \\
\hline
\end{tabular}

$S D=$ standard deviation; $V A C=$ vacuum-assisted closure; $S T S G=$ spilt-thickness skin grafting; $W I=$ wound infection; $S F=$ suction force; $I R I=$ ischaemia-reperfusion injury; CS = compartment syndrome; $R C T$ = randomised controlled trial.

Another modification of the technique was presented by Lee, who used negative-pressure wound therapy with automated wound solutions instillation and dwell time. ${ }^{20}$ Lee found that such a therapy promoted granulation tissue formation over the bone in a critically-ill and malnourished patient. Lee et al. recommended the use of an extended VAC therapy for large open fasciotomy wounds in eight patients with necrotising fasciitis, as it led to a significant reduction of wound area compared to the initial presentation without apparent complications. ${ }^{21}$ Kakagia suggested that low suction pressure should be applied to a maximum of $100 \mathrm{mmHg}$, along with another wound approximation technique in order to avoid wound tissue rigidity owing to overgranulation and the resultant limitation of wound approximation. ${ }^{22}$

However, the effect of a single VAC application may be comparable only to the effect of dressings but not to other wound approximation techniques. Compared to traditional dressings, VAC therapy has led to a significant acceleration of wound healing and closure in addition to less time required for skin grafting. ${ }^{23}$ Nonetheless, there may be a need for additional STSG in a considerable number of patients, ranging between $20-57 \%$, which increases the overall treatment duration and cost. ${ }^{16,17}$ In a prospective study, VAC therapy was associated with longer treatment durations and an increased demand for STSG with higher costs compared to the shoelace technique. ${ }^{24}$ In a descriptive case series, Fowler et al. found that four out of seven patients who underwent VAC-assisted closure required skin grafting; this proportion was significantly higher than in patients managed by vessel loop closure (odds ratio: 5.9, 95\% confidence interval: $1.11-31.24 ; P=0.04) .{ }^{25}$

Delayed epithelialisation, another VAC-related issue, may become evident due to excessive granulation tissue formation that may grow into the dressings, exposing the wound to inflammation and infection. ${ }^{24,26}$ In a recent retrospective study in children who underwent a lower extremity fasciotomy, VAC treatment was compared with a temporary synthetic skin replacement therapy and was associated with longer times to wound closure (9.4 versus 4.9 days) and more prolonged LOS (16.2 versus 9.9 days). ${ }^{27}$ VAC-assisted wound closure was also prolonged compared to wounds closed by the shoelace technique, as demonstrated in multiple studies [Table 1]..$^{24,25,28}$

\section{Dermal Apposition Techniques}

Several techniques have been described for gradual approximation of wound edges. These techniques are frequently performed, such as daily bedside suture tightening, which leads to a gradual increase in skin length and reduction in the force required to maintain that length. Therefore, primary wound closure is possible and can be achieved after 7-15 days. ${ }^{24}$ Gradual approximation can be achieved by multiple techniques such as using sutures, static tension devices and mechanical devices. 


\section{GRADUAL SUTURE APPROXIMATION TECHNIQUES}

The shoelace technique was first described in 1986 and employs vessel loops, which are threaded in a crisscross manner 48 hours after a fasciotomy ${ }^{29}$ subsequently, skin staples are used to secure the wound edges with regular loop-tightening every 48 hours [Table 1]. Intravenous analgaesia may be required during tightening sessions due to the associated pain. Ultimately, suturing of wound edges is performed, resulting in acceptable aesthetic outcomes and high wound closure rates. ${ }^{25}$ Simple silk-suturing may be performed in a shoelace pattern following fracture-related fasciotomies which may be sufficient for wound closure without complications as shown in a series of 19 patients. ${ }^{30}$

While the shoelace technique is safe, inexpensive and minimally interferes with mobility, it lacks adequate strength to close large wound gaps. In areas of high tension such as point-loading sites, the staples may be dislodged. ${ }^{24}$

As a result, several variations of the shoelace technique have been proposed. Branco et al. used an elastic wire instead of vessel loops in a patient following tibial fracture-related CS; wound closure was successful within seven days. ${ }^{31}$ Eid and Elsoufy used a shoelace apparatus consisting of one or two paediatric urinary catheters as well as skin staples without encountering major complications in a series of 17 patients with fracture-related CS. ${ }^{32}$ Galois et al. used wide drainage tubes containing sutures to increase the contact area between the muscles and sutures and prevent muscular injury. ${ }^{33}$ The drains were placed in contact with the muscles and were regularly tightened over the skin. ${ }^{33}$ Sawant and Hallett secured the ends of vessel loops using a paper-clip instead of securing them with endstaples and knots. ${ }^{34}$ This modification prevents pain and discomfort induced by tying and manipulation of the end-staples.

In addition, based on the results from eight emergency fasciotomies, Zenke et al. recommended the use of both VAC treatment and the shoelace technique to reduce the need of STSG and provide better aesthetic outcomes. ${ }^{35}$ Such a combination was helpful in wound approximation in patients with severe softtissue injuries or abdominal injuries and could shorten the total treatment time compared to when each technique is used individually. Murakami et al. used the vessel loop technique in addition to VAC treatment in a patient with CS after an ischaemia-reperfusion injury; wound closure was achieved within one week without complications. ${ }^{36}$ However, it should be noted that treatment costs would increase with the inclusion of VAC treatment and even more so if STSG is required. ${ }^{11,37}$ This might be of considerable importance in a milieu of limited healthcare expenditures and austerity.

Riedl et al. first described an alternative approach for wound approximation, where a subcuticular suture was placed directly following fasciotomy without applying tension. ${ }^{38}$ Within 3-5 days, progressive traction was applied and the patients were usually not required to undergo a secondary operation. Using this prepositioned intracutaneous suture technique, Janzing and Broos found that it provided excellent skin apposition within nine days of regular surgical wounds in five patients (100\%) with acute limb CS; however, its efficiency may be questionable in traumatic wounds with irregular edges. ${ }^{39}$ The subcuticular suture technique may be associated with inflammation around sutures and might lead to suture tears during closure attempts and subsequent suture replacement. ${ }^{39,40}$

\section{STATIC TENSION STRIPS}

Gradual closure of fasciotomy wounds can also be attained by applying non-invasive techniques relying on repeated application of plaster strips on the second day post-surgery. This method was initially reported by Mbubaegbu and Stallard who used two longitudinal strips on both sides of the wound with application of connecting (bridging) strips in an outpatient setting. ${ }^{41}$ New longitudinal- and cross-strips should be added every 2-3 weeks until full wound closure is achieved. When using this method, surgeons should monitor the development of granulation tissue, which may inhibit wound closure. Similarly, Harrah et al. placed $1.2 \mathrm{~cm}$ wide plaster strips in the same manner following application of a tincture of benzoin to decrease the risk of blistering and epidermal shearing. ${ }^{42}$ However, this technique may not be feasible on large wounds where more tension on the strips is required as they may not withstand the tension of the protruding muscles. Moreover, the resulting scar due to tension may not be aesthetically acceptable, except for small fasciotomy wounds. Weissman et al. applied the same method in a paediatric population and showed that wound closure was achieved in 15-26 days without major complications; they suggested that this is an appropriate technique for patients for whom surgical interventions are inadvisable. ${ }^{43}$

\section{DYNAMIC MECHANICAL DEVICES AND INNOVATIVE TOOLS}

There are many innovative mechanical devices and techniques that focus on dermal approximation to achieve wound closure [Table 2]. Commercially-available devices exploit skin-stretching properties and mechanical creep; however, their typical role on the 
Table 2: A summary of case series that employed dermal approximation techniques using dynamic mechanical devices/tools

\begin{tabular}{|c|c|c|c|c|c|c|}
\hline $\begin{array}{l}\text { Author and } \\
\text { year of study }\end{array}$ & Device name & $\begin{array}{l}\text { Number of } \\
\text { patients }\end{array}$ & $\begin{array}{l}\text { Treatment } \\
\text { duration in days }\end{array}$ & Advantages & Disadvantages & Complication \\
\hline \multicolumn{7}{|l|}{ Expensive device } \\
\hline $\begin{array}{l}\text { Barnea et al. }{ }^{57} \\
(2006)\end{array}$ & Wisebands device & 16 & $1-15$ & $\begin{array}{l}\text { Providing a feedback } \\
\text { control to safeguard } \\
\text { when excessive skin } \\
\text { tension is applied }\end{array}$ & $\begin{array}{l}\text { Expensive and not } \\
\text { readily available }\end{array}$ & $\begin{array}{l}\text { Sepsis }(n=1) \text {, pain } \\
(n=1) \text { and scar } \\
(n=1)\end{array}$ \\
\hline $\begin{array}{l}\text { Janzing and } \\
\operatorname{Broos}^{39}(2001)\end{array}$ & Marburger system & 5 & 9 & $\begin{array}{l}\text { Materials needed for } \\
\text { intracutaneous sutures } \\
\text { are readily available }\end{array}$ & Expensive & $\begin{array}{l}\text { Skin necrosis }(\mathrm{n}=2) \\
\text { and skin grafting } \\
(\mathrm{n}=2)\end{array}$ \\
\hline $\begin{array}{l}\text { Medina et } a l .{ }^{45} \\
(2008)\end{array}$ & $\begin{array}{c}\text { Silver Bullet } \\
\text { Wound Closure } \\
\text { Device }\end{array}$ & 8 & $5-10$ & Simple and efficacious & $\begin{array}{l}\text { Daily tightening, } \\
\text { numbness and } \\
\text { tenderness of the scar }\end{array}$ & $\begin{array}{l}\text { Pain }(n=2) \text {, scar } \\
(n=3) \text { and } \\
\text { numbness }(n=2)\end{array}$ \\
\hline $\begin{array}{l}\text { Ozyurtlu et al. } .^{58} \\
(2014)\end{array}$ & $\begin{array}{l}\text { V-Loc wound } \\
\text { closure device } \\
\text { using barbed } \\
\text { sutures }\end{array}$ & 5 & 8.6 & $\begin{array}{l}\text { Knotted sutures to } \\
\text { prevent wound pulling } \\
\text { back, faster tightening } \\
\text { procedure and use of } \\
\text { absorbable sutures }\end{array}$ & $\begin{array}{l}\text { Rupture or lockups of } \\
\text { the sutures }\end{array}$ & Necrosis $(n=1)$ \\
\hline $\begin{array}{l}\text { Taylor et al. }{ }^{47} \\
(2003)\end{array}$ & Anchors & 5 & $6-14$ & $\begin{array}{l}\text { Equal distribution of } \\
\text { tension forces }\end{array}$ & $\begin{array}{l}\text { Expensive and not } \\
\text { readily available }\end{array}$ & None \\
\hline \multicolumn{7}{|c|}{ Inexpensive device } \\
\hline $\begin{array}{l}\text { Eid and } \\
\text { Elsoufy }^{32} \text { (2012) }\end{array}$ & $\begin{array}{l}\text { Paediatric urinary } \\
\text { catheters and } \\
\text { staples }\end{array}$ & 17 & $\begin{array}{l}\text { Average of } \\
4.2 \text { tightening } \\
\text { sessions }\end{array}$ & $\begin{array}{l}\text { Readily available and } \\
\text { inexpensive }\end{array}$ & Point-loading & Skin necrosis $(\mathrm{n}=5)$ \\
\hline $\begin{array}{l}\text { Govaert and van } \\
\text { Helden }^{59}(2010)\end{array}$ & Ty-raps & 13 & $4-23$ & Stiff and very strong & Not readily available & Skin grafting $(\mathrm{n}=1)$ \\
\hline $\begin{array}{l}\text { Kenny et al. }{ }^{46} \\
(2018)\end{array}$ & Rubber bands & 17 & $\begin{array}{l}\text { No information } \\
\text { available }\end{array}$ & $\begin{array}{l}\text { Readily available and } \\
\text { used for large wounds }\end{array}$ & $\begin{array}{l}\text { More than one } \\
\text { application may be } \\
\text { needed and qualitative } \\
\text { assessment of the } \\
\text { required tension }\end{array}$ & Skin grafting $(\mathrm{n}=1)$ \\
\hline $\begin{array}{l}\text { Mittal et al. }{ }^{49} \\
(2018)\end{array}$ & Dermotaxis & 25 & 12 & $\begin{array}{l}\text { Easy to use and no } \\
\text { point-loading }\end{array}$ & K-wire cut-out & Skin grafting $(\mathrm{n}=2)$ \\
\hline $\begin{array}{l}\text { Pasha et al. }{ }^{60} \\
(2012)\end{array}$ & Pasha device & 9 & $5-8$ & $\begin{array}{l}\text { Simple, cheap and user } \\
\text { friendly }\end{array}$ & Not readily available & $\mathrm{WI}(\mathrm{n}=1)$ \\
\hline $\begin{array}{l}\text { Ravinder et al. } .^{48} \\
(2018)\end{array}$ & $\begin{array}{l}\text { Dermotaxis using } \\
\text { Ravinder et al's } \\
\text { skin traction }\end{array}$ & 100 & $8-15$ & $\begin{array}{l}\text { Can be used in wounds } \\
\text { with exposed bones }\end{array}$ & K-wire cut-out & Skin grafting $(\mathrm{n}=12)$ \\
\hline $\begin{array}{l}\text { Rijal et al. }{ }^{50} \\
(2011)\end{array}$ & $\begin{array}{l}\text { Circular rubber } \\
\text { bands plus } \\
\text { longitudinal } \\
\text { gauzes }\end{array}$ & 3 & 8 & $\begin{array}{l}\text { Inexpensive and } \\
\text { provides evenly } \\
\text { distributed point- } \\
\text { loading }\end{array}$ & $\begin{array}{l}\text { Rubber band breakage } \\
\text { and not suitable for } \\
\text { active bleeders }\end{array}$ & None \\
\hline $\begin{array}{l}\text { Suliman and } \\
\operatorname{Aizaz}^{51}(2008)\end{array}$ & Plastic bands & 5 & $4-12$ & $\begin{array}{l}\text { Simple, inexpensive and } \\
\text { readily available }\end{array}$ & Risk of infection & $\begin{array}{l}\text { Hypertrophic scar } \\
(\mathrm{n}=1) \text { and } \\
\text { WI }(\mathrm{n}=1)\end{array}$ \\
\hline $\begin{array}{l}\text { Walker et al. }{ }^{61} \\
(2012)\end{array}$ & $\begin{array}{l}\text { A silicon sheet } \\
\text { fixed with a } \\
\text { running Prolene } \\
\text { suture }\end{array}$ & 69 & 11.9 & $\begin{array}{l}\text { Safe, painless, provides } \\
\text { constant wound control } \\
\text { and easily removed }\end{array}$ & Risk of infection & $\operatorname{STSG}(\mathrm{n}=17)$ \\
\hline
\end{tabular}

WI = wound infection; STSG = spilt-thickness skin grafting.

biological creep seems to be less effective. For example, Sure-Closure (MedChem Products Inc, Woburn, Massachusetts, USA) employs frequent intraoperative tightening of the wound edges using two hooked, $\mathrm{U}$-shaped arms; this process is interspersed with a 10 minute period of loosening the mechanical device. ${ }^{44}$ The Silver Bullet Wound Closure Device (Boehringer Laboratories, Norristown, Pennsylvania, USA) is another mechanical device that relies on rotating an internal cylinder to tighten pre-inserted sutures that have passed from one wound side to the opposite edge. ${ }^{45}$ However, the use of some of these mechanical devices has been restricted to distinct medical centres due to increased experience with these sophisticated procedures. Moreover, the use of such devices may be criticised due to the need for multiple applications of the technique, limited availability, lack of effective treatment for large wounds and the increased risk of skin necrosis and bulkiness. ${ }^{46}$ Due to the potential costs of using these devices, they are generally limited to middle- or high-income countries such as USA, Canada and Belgium. ${ }^{39,45,47}$ For example, the costs of wound closure using the Sure-Closure (MedChem Products Inc) and Silver Bullet Wound Closure 
devices (Boehringer Laboratories) are \$300-\$500 and $\$ 575$ USD, respectively. ${ }^{45,47}$ Mechanical devices should only be used with sufficient clinical experience as the benefits of these devices may be questionable compared to other simple and approved techniques such as the shoelace or simple suture techniques.

On the other hand, several innovative approaches have been developed to provide simple and inexpensive solutions to close fasciotomy wounds. Ravinder et al's dermotaxis approach is a skin traction method involving two Kirschner wires which are connected by a specific compression device and are passed through the margins of the wound; subsequently, tightening is performed every 12 hours in a total of 5-7 tightening sessions. ${ }^{48}$ The overall cost of such a method was estimated to be \$5 USD per patient. ${ }^{49}$ Recently, Kenny et al. developed a rubber band-based technique that costs $<\$ 1$ USD for each application consisting of applying the rubber bands across the length of the wound or leaving the wound centre open according to the clinical condition with subsequent wound coverage with a dressing. ${ }^{46}$ VAC therapy can also be utilised with such techniques in cases of large-gapping wounds. Rijal et al. developed another technique based on tying circular rubber bands to the marginal staples in a luggage-tag tying manner in addition to placing longitudinal layers of gauzes on the muscles to absorb fluid or discharge. ${ }^{50}$ Suliman and Aizaz described a simple approach for wound closure using plastic bands which were originally used to bind electric cables (22 bands cost \$1 USD). ${ }^{51}$ Nonetheless, the use of these simple tools, including other dermato-traction techniques, may not be preferable in patients with atrophic, infected, doubtfully-viable or friable skin. However, STSG can be a better solution to maximise the cost-effectiveness of treatment.

\section{Non-Invasive Wound Closure- Optimising Approach}

\section{LIMB ELEVATION}

Bengezi and Vo recommended limb elevation to decrease the amount of time taken for oedema resolution and be able to perform a primary wound closure. ${ }^{52}$ This approach depends on the rigorous enforcement of patients to keep the affected limb elevated on either an intravenous pole or at least five pillows with frequent checking for the laxity of the surrounding skin for optimal wound closure. This method is simple, has minimal costs and provides superior cosmetic outcomes. However, it may not be suitable for large or severely-affected wounds.

\section{HEALING BY SECONDARY INTENTION}

Healing by using skin contraction for gradual fasciotomy wound approximation is possible and would decrease overall cost of treatment. ${ }^{53}$ However, wound closure only occurs after an average of 3-4 months and requires the patient to change their dressings 1-3 times during this period. In addition, complete normalisation of the scar conformation may take up to four years. Other limitations of this method include an increased risk of infection and muscular necrosis as well as significant delay implied in rehabilitation. Although healing by secondary intention has been abandoned in current surgical practice, it may be used in cases where delayed primary wound closure has failed or in associated wound-dehiscence circumstances. ${ }^{22,53}$

\section{Conclusion}

Both the amount of time taken to intervene and the fasciotomy technique that is used are crucial for optimal wound closure and may be more impactful than the type of wound closure technique itself. The current repertoire of methods of fasciotomy closure seems to be promising and additional methods are emerging. Generally, there is no preferred method for treatment, however, suture-based dermal approximation techniques are most widely used. In the instance of resource availability in developed countries, the outcomes of these techniques could be optimised by concurrent application of negative-pressure therapy. Surgeons should be aware of the advantages and limitations of each technique, in addition to the cost of treatment in low-income countries. Finally, non-invasive methods, such as the use of tension-inducing adhesive strips and limb elevation, may be considered for patients for whom surgical interventions are inadvisable.

\section{References}

1. Forsh DA, Wolinsky PR. Compartment Syndrome. In: Smith WR, Sthel PF, Eds. Management of Musculoskeletal Injuries in the Trauma Patient. New York, USA: Springer, 2014. Pp 225-42.

2. Saber A. Compartment syndromes. J Acute Dis 2014; 3:169-77. https://doi.org/10.1016/S2221-6189(14)60040-8.

3. Ojike NI, Roberts CS, Giannoudis PV. Compartment syndrome of the thigh: A systematic review. Injury 2010; 41:133-6. https://doi.org/10.1016/j.injury.2009.03.016.

4. Jauregui JJ, Yarmis SJ, Tsai J, Onuoha KO, Illical E, Paulino CB. Fasciotomy closure techniques. J Orthop Surg (Hong Kong) 2017; 25:2309499016684724. https://doi.org/10.1177/23094990 16684724 .

5. Donaldson J, Haddad B, Khan WS. The pathophysiology, diagnosis and current management of acute compartment syndrome. Open Orthop J 2014; 8:185-93. https://doi.org/10.2174/18743 25001408010185 
6. Han F, Daruwalla ZJ, Shen L, Kumar VP. A prospective study of surgical outcomes and quality of life in severe foot trauma and associated compartment syndrome after fasciotomy. J Foot Ankle Surg 2015; 54:417-23. https://doi.org/10.1053/j.jfas.201 4.09.015.

7. Potter MBK, Freedman LBA, Shuler MS. Fasciotomy wound management and closure. Tech Orthop 2014; 29:180-4. https://doi.org/10.1097/BTO.0000000000000109.

8. Hussain S, Limthongkul B, Humphreys T. The biomechanical properties of the skin. Dermatol Surg 2013; 39:193-203. https://doi.org/10.1111/dsu.12095.

9. Ganske I, Wall J. Skin Grafts. In: Meara JG, McClain CD, Mooney DP, Rogers Jr SO, Eds. Global Surgery and Anesthesia Manual: Providing Care in Resource-Limited Settings. Boca Raton, USA: CRC Press, 2014. Pp. 419.

10. Weaver MJ, Owen TM, Morgan JH, Harris MB. Delayed primary closure of fasciotomy incisions in the lower leg: Do we need to change our strategy? J Orthop Trauma 2015; 29:308-11. https://doi.org/10.1097/bot.0000000000000278.

11. Matt SE, Johnson LS, Shupp JW, Kheirbek T, Sava JA Management of fasciotomy wounds--Does the dressing matter? Am Surg 2011; 77:1656-60.

12. Rai A, Khalil S, Batra P, Gupta SK, Bhattacharya S, Dubey NK et al. Electrical injuries in urban children in New Delhi. Pediatr Emerg Care 2013; 29:342-5. https://doi.org/10.1097/ PEC.0b013e3182852f71.

13. Hazani R, Whitney R, Wilhelmi BJ. Optimizing aesthetic results in skin grafting. Am Surg 2012; 78:151-4.

14. Blonska-Staniec MK, Barczak AE, Garus A, Balchanowski N, Miszczuk JP. The use vacuum therapy in wound healing after fasciotomy in compartment syndrome - Case report and literature review. Acta Angiologica 2016; 22:158-63. https://doi.org/10.5603/AA.2016.0015.

15. Morykwas MJ, Howell H, Bleyer AJ, Molnar JA, Argenta LC. The effect of externally applied subatmospheric pressure on serum myoglobin levels after a prolonged crush/ischemia injury. J Trauma 2002; 53:537-40. https://doi.org/10.1097/00005373200209000-00023.

16. Zannis J, Angobaldo J, Marks M, DeFranzo A, David L, Molnar J, et al. Comparison of fasciotomy wound closures using traditional dressing changes and the vacuum-assisted closure device. Ann Plast Surg 2009; 62:407-9. https://doi.org/10.1097/SAP.0 b013e3181881b29.

17. Saziye K, Mustafa C, Ilker U, Afksendyios K. Comparison of vacuum-assisted closure device and conservative treatment for fasciotomy wound healing in ischaemia-reperfusion syndrome: Preliminary results. Int Wound J 2011; 8:229-36. https://doi. org/10.1111/j.1742-481X.2011.00773.x.

18. Yang CC, Chang DS, Webb LX. Vacuum-assisted closure for fasciotomy wounds following compartment syndrome of the leg. J Surg Orthop Adv 2006; 15:19-23.

19. Weiland DE. Fasciotomy closure using simultaneous vacuumassisted closure and hyperbaric oxygen. Am Surg 2007; 73:261-6.

20. Lee P. Treating fasciotomy wounds with Negative Pressure Wound Therapy with Instillation and Dwell Time (NPWTi-d). Cureus 2016; 8:e852. https://doi.org/10.7759/cureus.852.

21. Lee JY, Jung H, Kwon H, Jung SN. Extended negative pressure wound therapy-assisted dermatotraction for the closure of large open fasciotomy wounds in necrotizing fasciitis patients. World J Emerg Surg 2014; 9:29. https://doi.org/10.1186/17497922-9-29.

22. Kakagia D. How to close a limb fasciotomy wound: An overview of current techniques. Int J Low Extrem Wounds 2015; 14:268-76. https://doi.org/10.1177/1534734614550310.
23. Krticka M, Ira D, Bilik A, Rotschein P, Svancara J. Fasciotomy closure using negative pressure wound therapy in lower leg compartment syndrome. Bratisl Lek Listy 2016; 117:710-14. https://doi.org/10.4149/bll_2016_136.

24. Kakagia D, Karadimas EJ, Drosos G, Ververidis A, Trypsiannis G, Verettas D. Wound closure of leg fasciotomy: Comparison of vacuum-assisted closure versus shoelace technique. A randomised study. Injury 2014; 45:890-3. https://doi.org/10.1016/j.injury.20 12.02.002

25. Fowler JR, Kleiner MT, Das R, Gaughan JP, Rehman S. Assisted closure of fasciotomy wounds: A descriptive series and caution in patients with vascular injury. Bone Joint Res 2012; 1:31-5. https://doi.org/10.1302/2046-3758.13.2000022.

26. Saeed MU, Kennedy DJ. A retained sponge is a complication of vacuum-assisted closure therapy. Int J Low Extrem Wounds 2007; 6:153-4. https://doi.org/10.1177/1534734607305597.

27. Bussell HR, Aufdenblatten CA, Gruenenfelder C, Altermatt S, Tharakan SJ. Comparison of lower extremity fasciotomy wound closure techniques in children: Vacuum-assisted closure device versus temporary synthetic skin replacement. Eur J Trauma Emerg Surg 2018. https://doi.org/10.1007/s00068-018-0985-9.

28. Johnson LS, Chaar M, Ball CG, Perez S, Nicholas JM, Wyrzykowski AD, et al. Management of extremity fasciotomy sites prospective randomized evaluation of two techniques. Am J Surg 2018; 216:736-9. https://doi.org/10.1016/j.amjs urg.2018.07.033

29. Cohn BT, Shall J, Berkowitz M. Forearm fasciotomy for acute compartment syndrome: A new technique for delayed primary closure. Orthopedics 1986; 9:1243-6.

30. Saini RA, Sharma D, Shah N. Shoe lace technique, a simple and less expensive method for fasciotomy wound closure following compartment syndrome. Int J Orthop Sci 2018; 4:445-9. https://doi.org/10.22271/ortho.2018.v4.i1g.64.

31. Branco PS, Cardoso Junior M, Rotbande I, Ciraudo JA, Silva CR, Leal PC. Elastic suture (shoelace technique) for fasciotomy closure after treatment of compartmental syndrome associated to tibial fracture. Rev Bras Ortop 2016; 52:103-6. https://doi. org/10.1016/j.rboe.2016.11.004.

32. Eid A, Elsoufy M. Shoelace wound closure for the management of fracture-related fasciotomy wounds. ISRN Orthop 2012; 2012:528382. https://doi.org/10.5402/2012/528382.

33. Galois L, Pauchot J, Pfeffer F, Kermarrec I, Traversari R, Mainard D, et al. Modified shoelace technique for delayed primary closure of the thigh after acute compartment syndrome. Acta Orthop Belg 2002; 68:63-7.

34. Sawant MR, Hallett JP. The paper-clip modification to the vessel loop 'shoelace' technique for delayed primary closure of fasciotomies. Injury 2001; 32:619-20. https://doi.org/10.1016/ S0020-1383(01)00035-3.

35. Zenke Y, Inokuchi K, Okada H, Ooae K, Matsui K, Sakai A. Useful technique using negative pressure wound therapy on postoperative lower leg open wounds with compartment syndrome. Injury Extra 2014; 45:83-7. https://doi.org/10.1016/j. injury.2014.07.015

36. Murakami M, Morikage N, Samura M, Yamashita O, Suehiro K, Hamano K. Shoelace technique plus vacuum-assisted closure in leg fasciotomy. ANZ J Surg 2014; 84:795. https://doi.org/10. 1111 /ans.12662.

37. Erdös J, Dlaska C, Szatmary P, Humenberger M, Vécsei V, Hajdu S. Acute compartment syndrome in children: A case series in 24 patients and review of the literature. Int Orthop 2011; 35:569-75. https://doi.org/10.1007/s00264-010-1016-6.

38. Riedl S, Werner J, Göhring U, Meeder PJ. [The pre-positioned intracutaneous suture--a method for treatment of soft tissue defects after fascia splitting in acute compartment syndrome]. Chirurg 1994; 65:1052-5 
39. Janzing HM, Broos PL. Dermatotraction: An effective technique for the closure of fasciotomy wounds: A preliminary report of fifteen patients. J Orthop Trauma 2001; 15:438-41. https://doi. org/10.1097/00005131-200108000-00010.

40. Chiverton N, Redden JF. A new technique for delayed primary closure of fasciotomy wounds. Injury 2000; 31:21-4. https:// doi.org/10.1016/S0020-1383(99)00193-X.

41. Mbubaegbu CE, Stallard MC. A method of fasciotomy wound closure. Injury 1996; 27:613-15. https://doi.org/10.1016/S002 0-1383(96)00111-8.

42. Harrah J, Gates R, Carl J, Harrah JD. A simpler, less expensive technique for delayed primary closure of fasciotomies. Am J Surg 2000; 180:55-7. https://doi.org/10.1016/s0002-9610(00)0 0409-8.

43. Weissman O, Goldman N, Stavrou D, Barzilai L, Grabov Nardini G, Farber N, et al. Adhesive skin closure technique for closure of fasciotomy wounds in pediatric patients: A case series. Wounds 2015; 27:118-222.

44. Hirshowitz B, Lindenbaum E, Har-Shai Y. A skin-stretching device for the harnessing of the viscoelastic properties of skin. Plast Reconstr Surg 1993; 92:260-70. https://doi.org/10.1 097/00006534-199308000-00010.

45. Medina C, Spears J, Mitra A. The use of an innovative device for wound closure after upper extremity fasciotomy. Hand (N Y) 2008; 3:146-51. https://doi.org/10.1007/s11552-007-9082-y.

46. Kenny EM, Egro FM, Russavage JM, Spiess AM, Acartürk TO. Primary closure of wide fasciotomy and surgical wounds using rubber band-assisted external tissue expansion: A simple, safe, and cost-effective technique. Ann Plast Surg 2018; 81:344-52. https://doi.org/10.1097/sap.0000000000001506.

47. Taylor RC, Reitsma BJ, Sarazin S, Bell MG. Early results using a dynamic method for delayed primary closure of fasciotomy wounds. J Am Coll Surg 2003; 197:872-8. https://doi.org/10.1 016/s1072-7515(03)00646-x.

48. Ravinder S, Gill HS, Walia JPS, Brar BS, Nagra TS. Management of skin loss by dermotaxis. J Bone Joint Surg Br 2018; 90-B.

49. Mittal N, Bohat R, Virk JS, Mittal P. Dermotaxis v/s loop suture technique for closure of fasciotomy wounds: A study of 50 cases. Strategies Trauma Limb Reconstr 2018; 13:35-41. https://doi.org/10.1007/s11751-017-0299-1.
50. Rijal L, Nepal P, Adhikari A, Regmi S. Luggage tag tie technique for delayed primary closure of fasciotomy wounds. Eur J Orthop Surg Traumatol 2011; 21:449-52. https://doi.org/10.1007/s0059 $0-010-0729-y$.

51. Suliman MT, Aizaz S. Closing fasciotomy wounds using plastic bands: An alternative simple and cheap method. Ann Vasc Surg 2008; 22:697-700. https://doi.org/10.1016/j.avsg.2008.05.001.

52. Bengezi O, Vo A. Elevation as a treatment for fasciotomy wound closure. Can J Plast Surg 2013; 21:192-4. https://doi.org/10.11 77/229255031302100303

53. Boxer L, Buchman S. An alternative method for closure of fasciotomy wounds: Healing by secondary intention. Internet J Plast Surg 2002; 1:2

54. Zorrilla P, Marín A, Gómez LA, Salido JA. Shoelace technique for gradual closure of fasciotomy wounds. J Trauma 2005; 59:1515-17. https://doi.org/10.1097/01.ta.0000199242.24511.30.

55. Dahners LE. The running near-near-far-far stitch for closure of fasciotomies and other large wounds. Orthopedics 2003; 26:383-4.

56. Van der Velde M, Hudson DA. VADER (Vacuum-Assisted Dermal Recruitment): A new method of wound closure. Ann Plast Surg 2005; 55:660-4. https://doi.org/10.1097/01.sap.00001871 81.59748.19.

57. Barnea Y, Gur E, Amir A, Leshem D, Zaretski A, Miller E, et al. Delayed primary closure of fasciotomy wounds with Wisebands, a skin- and soft tissue-stretch device. Injury 2006; 37:561-6. https://doi.org/10.1016/j.injury.2006.02.056.

58. Ozyurtlu M, Altınkaya S, Baltu Y, Ozgenel GY. A new, simple technique for gradual primary closure of fasciotomy wounds. Ulus Travma Acil Cerrahi Derg 2014; 20:194-8. https://doi. org/10.5505/tjtes.2014.54077.

59. Govaert GA, van Helden S. Ty-raps in trauma: A novel closing technique of extremity fasciotomy wounds. J Trauma 2010; 69:972-5. https://doi.org/10.1097/TA.0b013e3181f2d9d3

60. Pasha IF, Qureshi MA, Arshad RM, Tahir UB, Akram M, Awais SM. Delayed primary closure of open double fasciotomy wounds at leg with "Pasha Device" a novel method. Ann King Edw Med Univ 2012; 18:168-73

61. Walker T, Gruler M, Ziemer G, Bail DH. The use of a silicon sheet for gradual wound closure after fasciotomy. J Vasc Surg 2012; 55:1826-8. https://doi.org/10.1016/j.jvs.2011.12.009. 